\title{
HISTÓRIA, POLÍTICA E SOCIEDADE: UMA ANÁLISE TEMÁTICA DAS LITERATURAS AFRICANAS PÓS-COLONIAIS
}

\author{
Adilson Vagner de Oliveira ${ }^{1}$ \\ Ana Cássia Gualda Bersani² \\ Karen Danielle Pinheiro ${ }^{3}$ \\ Thaís Fernandes de Almeida ${ }^{4}$
}

\begin{abstract}
Resumo: Este artigo analisa um conjunto de obras representativas das literaturas africanas pós-coloniais, a partir de recortes temáticos que transitam entre a história e a política das sociedades africanas. O trabalho apresenta uma série de leituras críticas sobre as obras $O$ melhor tempo é o presente (2014) de Nadine Gordimer, Um Grão de Trigo (2015) de Ngugi Wa Thiong’o, O Planalto e a Estepe (2009) de Pepetela e Elizabeth Costello (2004) de J. M. Coetzee, a fim de apontar os grandes temas dessas literaturas, com destaque à questão colonial e seus desdobramentos no presente, a história política das nações africanas e a discriminação racial, como elementos fundamentais para se compreender o universo literário africano.
\end{abstract}

Palavras-chave: Literatura Africana. Romance. Teoria. Pós-colonialismo

\section{Introdução}

Este trabalho analisa narrativas da África do Sul, de Angola e do Quênia, com o objetivo de apresentar alguns elementos temáticos mais frequentes que constituem as obras ficcionais africanas pós-coloniais, buscou-se construir um panorama interpretativo sobre um conjunto de ficções significativas recentes do continente. Inicialmente, tem-se a consagrada autora sul-africana, Nadine Gordimer (19232014), com sua última obra O melhor tempo é o presente (2014). A análise visa a

\footnotetext{
'Doutor em Ciência Política pela UFPE. Mestre em Estudos Literários pela UNEMAT. Docente do Instituto Federal de Mato Grosso - Campus Avançado Tangará da Serra.E-mail: adilson.oliveira@tga.ifmt.edu.br

${ }^{2}$ Graduanda em Arquitetura e Urbanismo pela Universidade do Estado de Mato Grosso. Membro do Grupo de Pesquisa “Literaturas Africanas: História, Política e Sociedade”. IFMT - Campus Avançado Tangará da Serra.E-mail: acgbmt@gmail.com

${ }^{3}$ Membro do Grupo de Pesquisa “Literaturas Africanas: História, Política e Sociedade”. IFMT - Campus Avançado Tangará da Serra. E-mail: kadanipinehiro@gmail.com

${ }^{4}$ Graduanda em Arquitetura e Urbanismo pela Universidade do Estado de Mato Grosso - UNEMAT no Campus Universitário Barra do Bugres. Membro do Grupo de Pesquisa “Literaturas Africanas: História, Política e Sociedade”. IFMT - Campus Avançado Tangará da Serra. E-mail: fernandesthais554@gmail.com. Cabe mencionar a colaboração de Beatriz Ramos Campos Sampaio, egressa do Instituto Federal de Mato Grosso Campus Avançado Tangará da Serra, que contribuiu nos processos de produção da pesquisa e desse artigo.
} 
compreender como a autora traduz os aspectos históricos e políticos da África do Sul para seus romances, de modo a instigar o leitor a refletir sobre a condição neocolonial dos países africanos independentes.

Em seguida, como corpus de análise sobre Angola, investigou-se a obra O Planalto e a Estepe (2009) de Pepetela. Na obra, pontos como política, sociedade, discriminação, tradição e cultura são abordados com o intuito de relatar as consequências de uma colonização traumática para o país, seguida de um regime socialista autoritário que produziu marcas profundas na história do continente, e principalmente, revelou os desafios enormes para a construção de sua própria identidade.

Em sua obra Um grão de Trigo (2015), Ngugi wa Thiong’o envolve os conflitos do período de colonização e pós-independência que o Quênia passou. Ngugi condensa todos esses acontecimentos em uma narrativa recheada de traições, desilusões, incompreensões sobre o próprio passado do país. Esses acontecimentos acabam por moldar o caráter de cada personagem e evidenciam o relacionamento conflituoso entre colonizado e colonizador.

J. M. Coetzee tem, como característica literária, o constante resgate de temas políticos, sociais e históricos em seus romances. O percurso cultural da África do Sul se constrói ficcionalmente na obra de Coetzee por meio da representação do encontro entre povos, do conflito racial e da violência pós-colonial. Na obra analisada nesse artigo Elizabeth Costello (2004), o autor explora o romance africano, contextualizando e explicando sua funcionalidade dentro do complexo processo cultural e histórico da África, deixando conceitos importantes sobre a literatura do continente.

\section{Perspectivas contemporâneas sobre o romance africano pós-colonial}

Em estudos sobre o romance pós-colonial, as investigações acerca dos projetos literários da África tomam as obras ficcionais do continente como objeto de análise e consequentemente produzem também um marco teórico solidário, muito necessário para se compreender a produção pós-colonial nos séculos XX e XXI. Trata-se de uma abordagem inovadora, pois, traz ao centro de discussão teórica a literatura africana em suas inúmeras temáticas. Neste trabalho, aprofundar as pesquisas sobre as literaturas da África do Sul, de Angola e do Quênia permite a compreensão mais ampla do processo histórico e cultural que o romance pós-colonial africano tem experimentado nas últimas décadas.

Para Oliveira (2018), a literatura africana tornou-se essencial para se compreender o universo histórico do continente, pois, reflete a formação cultural das identidades nacionais e revelam fatos marcantes na vida política de toda a África. Diante do reconhecimento cada vez maior das literaturas africanas e suas conquistas ante o mercado literário, se torna relevante o destaque sobre os aspectos que compõem as narrativas africanas contemporâneas. 
Ao longo de várias pesquisas recentes (OJAIDE, 1992; JULIEN, 1995; BONNICI, 1998; SALGADO e SEPÚLVEDA, 2000; BOEHMER, 2005; RIESZ, 2007; CARBONIERI et al. (2013) e MATA, 2014), revela-se a complexidade do empreendimento teórico ao buscar-se sintetizar a pluralidade literária do continente, em princípios conceituais da teoria do romance africano.

O continente africano, devido ao seu processo colonial no passado, por muito tempo sofreu por estereótipos eurocêntricos que inferiorizavam e subjugavam nações e sociedades locais, condenando culturas, tradições e valores que não eram adequados aos princípios ocidentais de ver o mundo. Nesse contexto, foram impostos padrões, normas e costumes à África e aos africanos, de modo a fazer com que a história cultural africana fosse alterada completamente e transformada pelos colonizadores europeus. Trata-se de um processo muito intenso de aproximação e dominação cultural que tem na literatura, um produto positivo dessa interação.

\begin{abstract}
Refazer a história é uma persistente crítica, sem glamour nenhum, eliminando oposições binárias e continuidades que emergem continuamente no suposto relato do real. A política cultural da repetição está sendo encenada com o gestual da política da ruptura estratégica, necessária, tendo em vista a independência política que é o requisito mínimo para a 'descolonização' (SPIVAK, 1994, p. 205).
\end{abstract}

Conforme o processo de descolonização relativamente recente dos países africanos se consolidou ao longo do século XX, projetos nacionalistas de recriar uma verdadeira África perdida num passado mítico foram sendo construídos, aos poucos, por intelectuais e escritores, e um elemento para recuperar essa historicidade africana tem sido a literatura, que tem a capacidade de mostrar novas perspectivas dos fatos, interpretações alternativas dos fenômenos políticos e sociais, além de permitir a projeção de valores e ideais plurais de identidades. Para Carbonieri, Freitas e Silva (2013, p. 02) “o romance africano ensaia novos caminhos, examinando as realidades das culturas africanas após o término da ocupação física por outras sociedades, num momento em que elas ainda são perpassadas pela luta contra a opressão de diversos tipos”, já que agora não é mais o colonizador que escreve sobre a África, mas, o próprio africano.

Desse modo, o romance africano apresenta vozes internas para seus narradores, releituras da história passam a fazer parte da composição narrativa, uma vez que o projeto literário comum se baseia na necessidade de olhar para as próprias sociedades locais, recontar o passado, resgatar heróis nacionais, denunciar as contradições internas e valorizar as tradições, por meio do discurso literário. Por isso, a escrita ficcional ganha espaço na produção cultural do continente, pois, pode funcionar de forma instrumental para colaborar com a reconstrução dos povos africanos. A descolonização político-administrativa dos países africanos permitiu o surgimento de novos discursos, novas verdades sobre o próprio território. "O romance africano nasce como uma herança da colonização europeia, 
mas também como um grito de revolta, um ato de resistência cultural, abrindo aos povos colonizados a possibilidade de afirmar sua identidade e narrar sua própria história” (CARBONIERI et al., 2013, p. 02).

\begin{abstract}
Os primeiros textos literários produzidos nas colônias, ainda durante o período de colonização, são escritos frequentemente por representantes do poder imperial, como colonos, viajantes e administradores coloniais, que compõem uma elite letrada identificada principalmente com o centro metropolitano. Ainda que esses escritos sejam capazes de fornecer uma imagem detalhada da paisagem e costumes dos países invadidos, eles não formam a base para uma cultura literária indígena e nem poderiam ser integrados à tradição cultural ancestral (CARBONIERI et. al., 2013, p. 10).
\end{abstract}

Os romances africanos só receberam ênfase em seu próprio continente na segunda metade do século XX, após o processo de descolonização, quando os africanos passaram a escrever suas obras, que até então eram criadas por colonizadores, com perspectivas eurocêntricas e de homogeneização dos povos africanos. Augel (2007) expõe em sua pesquisa que os próprios autores africanos entendem a linguagem utilizada pelos colonizadores anticolonialistas, ou seja, é evidente uma diferença discursiva entre as obras de colonizadores e colonizados. Assim, a literatura escrita após o processo de descolonização pode ser entendida como "pós-colonial”, não necessariamente pela sequência temporal, mas pela mudança do discurso, pois, permitiam-se perspectivas endógenas sobre os povos africanos e suas culturas (BOEHMER, 2005; RIESZ, 2007).

Através de um viés histórico, enfim os africanos poderiam se desenvolver no campo político, social e também literário. Porém, se pressupôs que as narrativas poderiam livrar das interferências dos colonizadores, conseguindo adquirir identidades locais, o que na realidade, não aconteceu, já que questões entre colonizador e colonizado mesmo após a descolonização prosseguiram acentuadas (BONNICI, 1998). Ou seja, a longo prazo, mesmo com a independência política e administrativa, os povos africanos continuaram seguindo padrões dos colonizadores, buscando ganhar espaço e reconhecimento em diversas áreas, tendo que se moldarem a instituições e padrões eurocêntricos.

No caso específico do romance pós-colonial, a característica mais marcante desse fenômeno é a hibridização, o próprio gênero literário, de origem europeia, se reconfigura como uma representação simbólica do encontro/choque entre culturas. O confronto entre colonizadores e colonizados reflete esse enfrentamento de concepções de mundo, valores e tradições, ultrapassou os limites interpessoais e políticos e migrou para a forma literária. Dessa maneira, o romance africano tornou-se um produto híbrido que se nutre de visões e percepções plurais, mescladas de valores africanos e europeus que a todo o mundo se estranham e se negociam (CARBONIERI et al., 2013). 
Dessa forma, a literatura pós-colonial teve que se submeter à estética europeia, ligada a um princípio global e homogêneo. Diante disso, a utilização da língua colonial para as produções pós-coloniais está também relacionada ao poder exercido pelos colonizadores e à diminuição das culturas nativas (BONNICI, 1998). Assim, dar voz às narrativas africanas escritas nas línguas dos colonizadores é afrontar o discurso pós-colonial e trazer à tona questões eurocêntricas, as obras africanas, em uma perspectiva mais amena, podem ainda ser vistas como o produto final, com relação aos fenômenos da colonização (JULIEN, 1995).

A ideia de pós-colonial, trazida dos anos 70, tinha como necessidade apenas a conservação e manutenção das obras dos nativos, na época considerados inferiores socialmente e intelectualmente (BONNICI, 1998). O autor ainda elucida o restabelecimento do valor das vozes dos colonizados para que façam parte também do material literário e a deformidade que foi criada pelos colonizadores nos elementos culturais africanos presentes ainda no sistema contemporâneo.

Portanto, logo após o término do período colonial, deu-se início um novo movimento, visando atribuir características próprias de escritas e deixar de lado toda a hierarquia literária no discurso colonial existente na época (JULIEN, 1995). O pós-colonial se trata, então, de uma visão do próprio colonizado, onde mostra todo o processo enfrentado e vivenciado por eles em diferentes situações. Assim, o ressurgir da literatura africana, especialmente o romance africano, faz com que apesar do mesmo possuir uma herança europeia se tenha "também como um grito de revolta, um ato de resistência cultural, abrindo aos povos colonizados a possibilidade de afirmar sua identidade e narrar sua própria história” (CARBONIERI et. al, 2013, p. 02).

Dessa maneira, ocorre uma transformação literária, e inclusão cultural, visto que após a descolonização, os aspectos da escrita ficcional são opostos daquilo já realizado anteriormente. É de fundamental importância à valorização da literatura, observando sua relevância para o crescimento da nação em diversas esferas, carregando papel essencial para identidade.

Creio que a literatura nacional é elemento indispensável, tão importante como outro qualquer, para a consolidação da independência. É um fator que ajuda a aumentar a unidade nacional, por ser veículo de situações, modos de vida e de pensar, dentro do país (SALGADO; SEPÚLVEDA, 2000, p. 153).

Ou seja, a literatura é responsável por causar grande impacto na sociedade, por ajudar a construir uma identidade nacional. Para Augel (2007), analisando as obras do continente africano, nota-se essas identidades, por unanimidade dos pensadores africanos, as tradições são baseadas em ideias de identidade que em hipótese alguma deve se distanciar do contexto socioeconômico.

Segundo Ojaide (1992, p. 55), as obras literárias africanas têm trazido uma reflexão sobre o colonialismo e suas respectivas consequências políticas e culturais. $\mathrm{O}$ que tem estimulado os autores a verem-se na responsabilidade de "purificar 
as mentes da sociedade”. Em outras palavras, os romances africanos têm sido utilizados como ferramenta para atentar as pessoas aos fatos ocorridos durante e após o colonialismo. Porém, "depois do momento inicial de sua implantação no continente, ele sofreu diversas transformações que inclusive o afastaram do nacionalismo e da euforia pela emancipação política que marcaram suas primeiras fases" (CARBONIERI et. al, 2013, p. 02).

Segundo Julien (1995), as narrativas africanas apresentam fatores que não são tão perceptíveis a uma primeira vista sobre o fenômeno da escrita pós-colonial; como a negativa de nacionalidade, para a autora, as obras africanas são essencialmente ligadas às realidades dos povos e lugares narrados, bem como a exposição do abuso de poder e como a sociedade contemporânea foi afetada. Desse modo, para a criação de novas teorias sobre as narrativas africanas, são necessários que sejam criados novos princípios sobre a identidade, liberdade e ainda uma maior noção e aceitação quanto ao nacionalismo.

Ojaide (1992, p.44) destaca que as principais obras africanas tratam assuntos ligados ao julgamento de "práticas sociais e políticas negativas". Ele prossegue afirmando que nenhuma única literatura africana é apenas uma arte, mas todas elas possuem uma mensagem explícita ligada a fatores sociais. Desta maneira, pode-se dizer que os grandes escritores africanos têm voltado seus olhares para os acontecimentos enfrentados pela sociedade africana como uma maneira de retratar as vivências da população local e expressar críticas sociais com as diferentes regiões que compõem a África.

Portanto, o romance africano é integralmente social em seu compromisso com as populações africanas, o universo político, religioso e cultural de seus povos faz parte do material temático, não como uma escolha aleatória, trata-se de um projeto ético de levar a sociedade africana para dentro das narrativas ficcionais, a fim de dar espaço a discursos silenciados historicamente. Por isso, a questão étnica se processa intensamente dentro dos enredos, a diferenciação entre os povos, os conflitos e consequências do encontro com os colonizadores, o choque da tradição e a modernidade, a pluralidade religiosa e evidentemente, a questão nacional. A necessidade de consolidar o espírito de nação nos vários países do continente faz da literatura africana um espaço de enriquecimento e reconhecimento das histórias locais, as sociedades ainda se reorganizam cultural e socialmente, mesmo depois de décadas de descolonização.

A literatura africana está recheada de "traços culturais", sendo usados gêneros como poesia, ficção e drama para transmitir a grandiosidade da cultura, da terra, dos conflitos sociais, rituais e outros diversos aspectos que trazem uma observação moral e ética acerca das obras. Como também têm sido utilizadas outras literaturas, além da africana, para unificar e relacionar as ideias apresentadas nas obras (OJAIDE, 1992). Nesse diálogo com outras literaturas, o romance africano se universaliza cada vez mais, passando a discutir questões existencialistas, a papel da mulher na sociedade africana, a maternidade e as relações humanas, como um todo. 
Soyinka (1976) elucida que as demais obras literárias se encaixam e se complementam com a literatura africana. Dessa forma, entende-se que, de certo modo, as literaturas africanas têm apresentado características relevantes de tradições, culturas em relação, e outros aspectos de diferentes povos, com o intuito de mostrar que apesar das diferenças étnicas existe uma semelhança entre elas, um laço que as conecta coletivamente.

Na atualidade, o romance africano ensaia novos caminhos, examinando
as realidades das culturas africanas após o término da ocupação física por
outras sociedades, num momento em que elas ainda são perpassadas pela
luta contra a opressão de diversos tipos. Nesse sentido, ele assume um
lugar de grande interesse para a crítica contemporânea, ao lado de outras
manifestações pós-coloniais, que parecem constituir o que há de mais
relevante na produção literária atual (CARBONIERI et. al, 2013, p. 02).

Os novos caminhos para o romance africano levam a universalização da literatura africana. Assim, as questões extremamente particulares da história local se convertem em planos de fundo para enredos cada vez com maior poder de alcance. Ampliando-se estrutural e esteticamente, sem desconsiderar os aspectos culturais locais.

O tempo no sistema literário africano não é algo engessado, ou seja, é cíclico. No romance africano, a quebra do tempo linear pode significar um problema, caso o leitor não consiga identificar a constante mudança e relatividade do tempo nas obras literárias (OJAIDE, 1997). Sendo assim, não se trata de uma literatura imóvel, mas de obras que podem apresentar no decorrer do enredo tempos diferentes, para trazer mais informações e proporcionar um maior entendimento dos fatos ocorridos na obra. Assim, como pontuam Carbonieri et al. (2013, p. 03) em sua maioria "a produção de autores oriundos dos contextos das culturas que foram, em algum momento da sua história, colonizadas pelas potências europeias que está transformando o modo como encaramos o romance na atualidade”.

Nessa perspectiva, por diversas vezes, as obras apresentam características nacionais e regionais, a fim de apresentar ao leitor elementos de um processo cultural plural e a história política das nações africanas, com fortes traços de interação com a realidade. Hall (2004, p.52) diz que "Ela [a narrativa nacional] dá significado e importância à nossa monótona existência, conectando nossas vidas cotidianas com um destino nacional que preexiste a nós e continua existindo após nossa morte”.

Mesmo com o distanciamento da escrita eurocêntrica, a sociedade ainda se dirige ao romance africano como um gênero periférico, ou seja, ainda julgam que o verdadeiro padrão de escrita e embasamento são os de origem europeia. Porém, o romance africano surgiu da mistura da cultura europeia com a sua própria, afinal a África foi colônia de países europeus durante vários anos, obrigando o continente a adotar os comportamentos e ideais por um longo período. Tais fatos 
comprovam que, os escritores e as narrativas, adquiriram tanto a cultura africana quanto a europeia para a escrita, que ainda é julgada em diversos países e locais do mundo, como sugere Nkosi (1981):

O romance africano nas línguas europeias às vezes é condenado por sua dupla ancestralidade, que é tanto africana como europeia. Sendo o filho bastardo de muitas culturas e gêneros, o acumulador de muitos estilos e tradições, o romance africano moderno, segundo geralmente se afirmam, não pode refletir propriamente a realidade africana. (...) Mas a verdade é que a mesma diversidade do romance africano e a variedade das línguas em que ele é escrito, refletem mais precisamente do que qualquer coisa das realidades da África moderna; e o que é visto como uma mistura embaraçosa de estilos e tradições, sendo frequentemente uma fonte de força e vitalidade, não a causa de uma fraqueza e uma diminuição da capacidade de revelação (NKOSI, 1981, p. 53).

Portanto, a dupla ancestralidade das narrativas africanas não é um quesito impróprio, mas, uma vertente que sempre é abordada nas escritas de forma detalhada, afinal foi esse vetor que tornou o continente africano o que ele é hoje em sua essência. Todos os acontecimentos históricos, sociais e políticos agora são abordados de maneira ficcional, pois os escritores se baseiam em todas essas esferas para produzir suas obras, e, acima de tudo, retratar ao máximo a identidade nacional da África.

As literaturas africanas podem se destacar em dois cenários, o primeiro, como uma afirmação ao leque de assuntos que podem ser abordados em toda e qualquer literatura, e em segunda análise, podem ser reconhecidas como objeto de estudos científicos, uma vez que abrangem temas que recorrem a certos engajamentos políticos, sociais e históricos, termos que se desprendem da identidade literária comum e que podem causar estranhamento se analisado de modo eurocêntrico (JULIEN, 1995).

Assim como em obras de outros continentes, as obras africanas vivem em um constante dilema entre manter a tradição ou buscar a modernidade, e ainda que exista um anseio sobre manter a tradição, ela é dinâmica e em algum momento, dessa forma, o romance africano permanece com uma característica tradicional em suas obras, a valorização de um continente considerado subalterno, que agora tem vozes para expressar suas inquietações diante do cotidiano. Uma primeira motivação pode residir no fato da situação de pós-colonialidade manter evidente um índice de pobreza, corrupção e violência, sustentada ainda pela dialética hegemonia/subalternidade e parecida com a dinâmica do período colonial (MATA, 2014).

De acordo com Julien (1995) as narrativas africanas são o resultado não apenas de como uma literatura nova se aprimorou, mas de como suas produções continuam a contribuir para o crescimento de questões culturais, acima do período da história em que se encontram. Sendo assim, as literaturas africanas conquistam cada vez mais espaço e constroem uma identidade ainda mais forte sobre seus costumes, tradições e conflitos vivenciados, intensificando a ideia de uma nação africana. 


\section{0 romance de Nadine Gordimer e sua teoria}

Obra de uma das maiores escritoras sul-africana Nadine Gordimer (1923-2014); O melhor tempo é o presente (2014) é um romance característico sul-africano da autora que aborda questões históricas e principalmente sócio-políticas, tendo ainda como plano de fundo o fim do regime de segregação racial, o apartheid que marcou profundamente a África do Sul durante todo o século XX, além de ser o último livro da escritora.

Marek Pawlicki (2013) enfatiza a lealdade de Nadine Gordimer em retratar os problemas e transformações sócio-políticas da África do Sul em todas as suas obras, algo muito reconhecido e admirado por diversos críticos. Na perspectiva de Pawlicki (2013), quando Gordimer expõe em sua escrita os problemas sócio-políticos do país, se deve ao fato de que ela sofreu com a influência de um grande teórico sobre o colonialismo, sendo este o filósofo e psiquiatra Frantz Fanon.

Em termos sintéticos, o romance se concentra na vida de Rebecca Jabulile e Steven Reed, um casal unido pela luta contra o regime de segregação e que mesmo diante das inúmeras dificuldades nutriram um amor clandestino até o momento do pós-apartheid, onde agora tentam administrar suas vidas da melhor forma possível, num país onde o regime do apartheid ainda tem seus vestígios e que sofre com uma grande tensão política devido às eleições que se aproximam, além da chegada de refugiados ao país.

Jabulile é filha do presbítero da igreja metodista e diretor da escola local para meninos, além de tido como o líder zulu do local, desde cedo incentivou os estudos de sua filha, visando a um futuro aquém dos costumes da aldeia. Jabu lutou contra o regime que se instaurou em seu país e foi até mesmo presa, mas nunca deixou seus ideais longe e nem mesmo seus estudos, se transformando então em uma advogada. Foi em meio à luta que Jabu conheceu seu marido Steven Reed, um homem branco com origens judaicas, que mesmo sendo da classe média, lutava pela igualdade e a democracia em seu país, os dois viveram um amor ilegal até que o fim do regime fosse decretado e eles pudessem buscar algo além de se esconderem em Glengrove Place para criarem sua filha Sindiswa em uma casa onde mal cabiam.

Com o fim do regime, Steven vê a oportunidade de mudanças, já que agora o amor deles não era crime e como tinham uma criança, precisavam se mudar para um lugar mais seguro, sendo este um subúrbio, onde os brancos tinham morado antes de mudar-se para condomínios fechados, com mais segurança e que agora eram alugados para diversos colegas, tendo ainda na vizinhança vários amigos feitos na luta.

Deixar para trás, um salto no espaço. Sair do lugar que os recolheu num tempo em que lugar algum, nem ninguém, lhes permitiam estar juntos, como homem e mulher. A vida clandestina é o segredo humano precioso, a lei não permitia, a igreja não os casava, nem a dele, para os brancos, nem a dela, para negros. Glengrove Place. O lugar. Nosso lugar (GORDIMER,2014, p. 27). 
Após a mudança para o subúrbio, o casal passa a tomar suas decisões com mais cautela, pois possuem uma filha, e querem que o futuro dela seja o melhor, por mais que o país esteja uma bagunça política, simples questões, como em qual escola a menina vai estudar, demonstram a criação de cada parte do casal e as suas preocupações, o mesmo acontece quando o segundo filho do casal; Gary Elias chega.

A ideia de uma família formada a partir da necessidade de sobreviver, sem éditos religiosos (a igreja metodista do pai de Jabu, a sinagoga pela qual a mãe de Steve havia optado ao insistir que os filhos fossem circuncidados), era como uma disciplina herdada das circunstâncias de uma luta pela liberdade que não se questionava, que era algo natural [...] (GORDIMER, 2014, p. 124).

O cenário que a África do Sul se encontra na trama, é de um pós-apartheid onde nas ruas ainda se encontram violência e desigualdade e num período de eleições, marcado por escândalos dos candidatos e diversos partidos políticos. A autora apresenta em sua obra personagens que se questionam sobre os líderes e a capacidade dos mesmos; pois eles lutaram contra o regime, mas agora quando se encontram presentes na política se vendem por propinas e entram na corrupção, traindo o próprio povo que lutou ao seu lado por uma África do Sul mais justa (PAWLICKI, 2013).

Pawlicki (2013) ainda reforça que tal perspectiva e posição da autora, quanto aos líderes que buscam governar o país, se conectam com a ideia do neocolonialismo, sendo possível abordar novamente Fanon, ao salientar a transformação do representante do povo em alguém que por sede de poder opera apenas para a vontade das elites nacionais e se esquece da sua população carente.

O Mandela teve que enfrentar o clima de ressaca quando todo mundo acordou depois da grande festa, LI-BER-DA-DE LI-BER-DA-DE LI-BERDA-DE. Mas ainda tinha todo aquele entusiasmo, a... Como é que se diz? Confiança absoluta que a pessoa do Mandela inspirava quando estava no poder, fazendo as mudanças: as mudanças imediatas que eram possíveis. Agora são outros quinhentos... O governo tem que pegar a pá e começar a construir no lugar onde a gente demoliu o apartheid. Por quanto tempo os brancos vão continuar dominando a economia? Tirando um punhado de negros que conseguiram adquirir o know-how necessário, quantos vão conseguir entrar nesse clube fechado da elite poderosa? Quem é que vai mudar a hierarquia das minas, de cima para baixo? A galinha dos ovos de ouro responsável pela riqueza do país, os negros, é que continua a botar os ovos; enquanto os brancos, graças à Anglo-American \& Co., faturam os lucros da bolsa (GORDIMER, 2014, p. 36).

As consequências do término formal do regime de apartheid são inúmeras, como o aumento explícito da violência e do racismo em escolas e em outros espaços de interação racial. Pawlicki (2013) elucida o modo como a desigualdade social era gritante no país, de tal forma que a maioria dos negros trabalhava 
para a minoria branca continuar no poder, ou seja, um sistema estruturado de discriminação, cujas possibilidades de movimentação social se demonstravam ainda incipientes. Na obra, durante os almoços com os companheiros políticos, eram debatidos os rumos que o país estava tomando e em qual partido o futuro deles era menos incerto.

- Por que é que a gente faz o que os brancos fazem nos países deles? O que é que a gente tem a ver com isso? Nós não somos mais as colônias negras deles. -Ele percebeu, mas não entendeu mal, a justaposição de contrários: brancos e negros, o "nós" que excluía o homem dela, ele, de sua identidade solidária. Jabu se sente envergonhada pela traição dos negros, um grupo ao qual ela pertence, perpetrada por eles próprios; ainda que o racismo não faça parte de sua vida, é provado de modo definitivo pela existência de seus dois filhos? (GORDIMER, 2014, p. 156).

Outro problema que assola o país é a chegada de refugiados dos países vizinhos, que de tão pobres viviam nas ruas sob condições precárias e mendigando alimentos. Nadine apresenta por meio dos imigrantes que fugiram das opressões políticas de sua terra natal, um dos tipos de violência que se instaurou na África do Sul, assim como a antipatia dos patriarcas que responsabilizam os pobres imigrantes de roubarem os empregos, os recursos e ainda degradar suas ruas e calçadas (PAWLICKI, 2013).

Cada um tem que ficar no seu país pra consertar as coisas, e não fugir, nós nunca fugimos, ficamos em KwaZulu mesmo no tempo que os bôeres, os brancos na mina de carvão pagavam uma mixaria pros nossos homens, não dava nem mesmo pra levar as crianças pra escola, e adoecendo, adoecendo lá no fundo das minas, nós ficamos e fomos fortes pro país dar certo. Se essa gente não for embora, a gente vai ter que expulsar... (GORDIMER, 2014, p. 248).

A autora envolve em seu romance as dificuldades e preconceitos que acontecem dentro do próprio país, levantando questões de xenofobia e trazendo a ideia de migração para os próprios personagens, que procuram sair do meio de tanta desigualdade e confusão. Deste modo, Steven propõe a Jabu a migração para a Austrália, onde poderiam ter uma vida melhor e não deixar que seus filhos vivessem em um país violento e em processo de mudanças políticas. Pondo em jogo todo o seu passado de lutas por direitos e igualdade, deixando para trás ainda suas famílias e consequentemente a cultura da qual Jabu compartilhava com KwaZulu e seu Baba.

Não dá pra viver com aquela mentira, aquele fingimento. Que adianta ser professor assistente, ser advogada, num país onde a educação é um somatório de escolas que produzem alunos para serem aceitos como estudantes universitários sem o nível mínimo necessário para realizar o curso que escolheram? A lei contorna as acusações de corrupção contra camaradas acusados que têm altos cargos. É uma desculpa esfarrapada 
citar os filhos quando se toma uma decisão. Mas Sindiswa e Gary Elias cresceram para herdar tudo isso, tudo aquilo. Crianças que foram geradas na fé nem presente que não se materializou. Nenhum sinal da igualdade da fusão que eles representam, negro com branco, naquele país, nascido da Luta, que é o país mais desigual do mundo (GORDIMER, 2014, p. 456).

Para Pawlick (2013), o casal Jabu e Steve está impactado com a desigualdade racial que ainda prevalece e desfavorece inúmeras pessoas na nova África do Sul que não possui mais um regime de segregação, mas está longe de possuir uma igualdade racial e social. Um impacto considerado, de certo modo, uma inocência do casal para com o almejado desenvolvimento de um país após o fim da luta.

Diante das diversas transformações e crises pelo qual o país passa, a ideia de emigrar para a Austrália se torna cada vez mais atrativa, mesmo com todas as dificuldades que encontrariam lá, mas ao mesmo tempo errada, pois estariam deixando seus companheiros da luta sozinhos com um país em caos. No dia da despedida, observando tudo o que conquistaram em questões de militância, pessoais e profissionais, decidem que não deixariam seus ideais de um país melhor e justo para trás, resolvendo assim ficar para lutar novamente, agora por uma África do Sul justa e democrática.

\section{Planalto e a Estepe de Pepetela: os enlaces entre literatura e política}

Em O Planalto e a Estepe "Angola, dos anos 60 aos nossos dias. A história real de um amor impossível" (2009), Pepetela resgata por meio de fatos reais vinculado ao fictício, a história e a identidade africana. A obra relata o amor proibido entre o angolano Julio e a mongol Sarangerel, uma história que se passa nos anos 60, em uma época onde até mesmo o amor era decidido por meio da política, tendo como plano de fundo o período socialista da União Soviética, e como esse regime se espalhou pela Rússia, Angola, Mongólia e Cuba de diferentes formas, apesar de possuírem os mesmos princípios.

A obra começa com Julio contando sua história, descendência e mocidade. Logo nas primeiras páginas é possível analisar os aspectos coloniais e de discriminação do negro. Julio era de família classe média e branca, porém tinha muitos amigos negros, e sua irmã Olga, em uma conversa lhe disse:

- Devias brincar com teus colegas de escola e não com esses.

- Porquê?

- Porque eles são pretos e nós brancos [...] 
Continuei, porém, a brincar com os meus amigos. À volta de casa não tinha outros. Mas, não gostava deles por isso. Gostava por serem meus amigos verdadeiros, me lembre deles quanto era muito pequeno e crescemos juntos. Tinha outros amigos, alguns companheiros de escola. Branco quase todos. Um ou outro mestiço. Não me lembro de nenhum negro na escola. Mas devia haver, pois se dizia Salazar construiu uma Angola multirracial” (PEPETELA, 2009, p. 12-13).

Porém, ele não se importava com a cor, então, com sua cabeça de criança, não conseguia perceber o meio preconceituoso ao qual estava inserido, e somente depois de adulto chega à conclusão: "só hoje sou capaz de reparar terem cores diferentes dos outros da escola. Na época éramos todos iguais, julgava eu. Não éramos afinal, havia racismo" (PEPETELA, 2009, p.13). Sua irmã Olga em praticamente todos os momentos da obra se mostra preconceituosa, em uma passagem Julio afirma: "Olga era racista, desde pequena dizia, não gosto nada de negros. Devia ter ouvido dos colonos vezes sem conta com afirmações desse género e aprendeu a frase" (PEPETELA, 2009, p.13). Assim é possível expor o racismo e estereótipos enraizados na sociedade e passado, mesmo que subliminarmente, pelas culturas e tradições, não somente africanas.

A evidência para isso está quando Julio, ao atingir sua adolescência vai com seu amigo negro João a uma cubata (bordel) de duas irmãs também negras, chegando lá uma das irmãs diz "tu está bem, que és branco, mas ele não [...] o dinheiro é igual disse João. Pois, mas a cor não é, disse a irmã” (PEPETELA, 2009, p. 18). Julio apesar de confuso, entra na cubada, mas no final pergunta o porquê de recursar o da tua cor e ela lhe responde: "porque se um branco souber que me deitei com um negro, não vai querer se deitar mais comigo. E os brancos é que têm dinheiro" (PEPETELA, 2009, p.28). Diante disso, o racismo colonial é implantado não somente nos brancos, mas os negros acabam sendo sujeitados a praticá-lo também, por motivo de domínio territorial e cultural.

O João devia ser amigo dos brancos, era obrigado pela lei e pela Igreja a ser amigo dos brancos, senão levava porrada. Os brancos é que não deviam ser amigos dos pretos (PEPETELA, 2009, p. 22).

Ainda indignado com o racismo e a forma que seu amigo João era tratado, resolveu conversar com seu professor de filosofia sobre Deus e o comunismo que era pregado no seu país.

Quanto ao bolchevique, era simples explicar, os comunistas russos assim se chamavam e ele até podia me explicar porque mais tarde, mas importante agora era isso de ser amigo ou não dos pretos e insistiu, Jesus Cristo disse para sermos todos irmãos e eu fazia muito bem em ser amigo de todos, não havia nisso pecado, antes pelo contrário, pecadores eram os que diziam só os pretos podem ser amigos dos brancos, não o inverso. Esses são racistas e colonialistas (PEPETELA, 2009, p. 23). 
Assim, os colonialistas são "os que querem que os africanos sejam sempre inferiores, sem direitos de gente na sua própria terra” (PEPETELA, 2009, p.23). E diante desse cenário controverso, ele decide ir para Portugal estudar medicina, mas logo percebe que sua vontade é entrar na política e participar da guerra, pois nesse cenário se sente inútil como médico, e viaja para Moscou. Lá faz amigos de várias origens distintas, um deles é Moussa, que possuía opinião parecida com a sua e por isso eles conversavam sobre política e ideias. Em uma dessas discussões eles chegam à conclusão de que por mais que o colonizado queira sair dessa condição de subordinado, ele acaba por contribuir com o colonizador.

Falamos muito sobre casos como esses, acontecendo um pouco por toda a África. Moussa era da minha opinião, era mais difícil ver duas empresas africanas cooperarem do que uma africana com uma europeia, o mesmo se passando com os Estados africanos entre si.

- Pobre África, viramos as costas uns aos outros e quem lucra é o antigo colonizador (PEPETELA, 2009, p.180).

Da mesma forma aconteceu na aculturação colonial, onde a religião foi oprimida e condenada, impondo-lhes crenças que não faziam parte do seu cotidiano, e mesmo depois de anos, a fim de tentar manter sua doutrina religiosa africana, o enraizamento eurocêntrico já tinha modificado a tradição, não sendo mais a mesma.

Convém explicar, as pessoas são conservadoras e passam a vida a falar das tradições africanas, criticando culturas alheias e suas imposições neocoloniais, mas se socorrem facilmente a lendas estrangeiras (PEPETELA, 2009, p. 92).

Com a pretensão de erradicar a discriminação e fazer uma nação só, o comunismo prega a igualdade entre os povos, independentemente de sua religião, cor, etnia, sexualidade, etc. Porém, quando o angolano Julio se envolve com a mongol Sarangerel, filha do ministro da Mongólia, ele percebe que toda a ideologia de igualdade pregada não existe de fato, e fica mais evidente quando Sarangeral descobre que está grávida e é sequestrada por seu próprio pai e levada de volta a seu país. As tentativas falhas de Julio conseguir visto e propor casamento mostram somente a hipocrisia de um sistema carente de bases que o tornem possível, fazendo com que Julio conseguisse reencontrar Sarangerel e sua filha depois de três décadas.

O socialismo democrático tornou-se uma ideologia utópica diante da lógica de poder propagada nas nações socialistas, o poder burocrático estabelecia-se como um dogma excludente e repressor (OLIVEIRA, 2014, p. 13). 
Sem sua grande paixão, Julio dedicou-se exclusivamente a sua carreira, se tornando membro ativo do movimento de libertação, estando sempre junto com o exército defendendo o socialismo, mesmo sabendo de suas contradições internas.

Por fim, a obra tenta mostrar como a colonização, seguida do período da União Soviética afetou a África como um todo, e como o abuso de poder daqueles que se intitulavam superiores, degradou a estabilidade social e econômica de uma África que havia iniciado seu processo de pós-colonização, o que resultou em um contínuo conflito de identidade cultural, tanto para os de fora, como aos africanos.

No reencontro de Julio e Sarangerel, ele leva sua filha para conhecer sua terra, onde nascera e passara sua mocidade. E relata as perspectivas dela diante do cenário.

Gostou da casa, gostou de Dona Dulce, gostou do cheiro, do clima, da balbúrdia da cidade, do nosso desgoverno e indisciplina de todos os dias, gostou de tudo. Estava num sétimo céu que nunca tinha conhecido, me confessou um dia. Era uma África diferente da que tinha imaginado, mas todos sabemos como África sabe se transformar naquela que cada um tem dentro de si (PEPETELA, 2009, p. 174).

Isso mostra que não somente a identidade africana nacional foi afetada, mas como os estereótipos sobre o continente e seu povo foram explanados de forma subjugada por todas as nações, de forma que não somente a África, como território e economia, perdeu seu valor aos olhos do mundo, como os próprios africanos que buscam resgatar a sua própria identidade, assim como parte daquela terra e de toda sua trajetória historiográfica, a fim de retomar aquilo que é seu de direito, o respeito e igualdade.

\section{Um grão de trigo de Ngugi Wa Thiong'o}

O processo de descolonização deixou marcas irreparáveis nos países do continente africano, sendo refletidas dentro das narrativas ficcionais que compõem o sistema literário africano. Para Menezes (2016, p.40) “a descolonização inclui a análise de lutas, de compromissos, de acordos e de resultados, o repensar dos aspectos fundamentais, de quem tem o poder e como o utiliza". Dentro dessa perspectiva, a região do Quênia, já abrigou grandes conflitos internos entre colonizado e colonizador. A população era completamente isenta de representatividade política, sendo marginalizada economicamente, através das incertezas sobre a propriedade de suas terras.

Kanter (2015) elucida que a constante repressão da população, com a tomada de suas terras e a proibição de acesso a sindicatos contribuíram para que muitos quenianos se rebelassem contra o regime colonial. E assim, organizassem movimentos anticolonialistas, com a principal etnia do Quênia, os Kikuios, ficando reconhecidos como Mau-Mau. Trata-se de um dos principais grupos 
de resistência à administração colonial do país, suas ações ficaram conhecidas em todo o continente.

No romance Um grão de trigo (2015) do escritor queniano Ngugi Wa Thiong'o, pode-se perceber a retratação das vivências dos personagens durante o período de descolonização do Quênia, como uma forma de crítica ao passado. A obra narra o drama pessoal de diferentes personagens que compõem o movimento anticolonialista Terra e Liberdade, ou mais conhecido como Mau-Mau. Como também ilustra a luta pela conquista da independência. O protagonista Mugo, é visto como um herói por todos da aldeia Thabaí, após ter sido preso pelos colonizadores ingleses e supostamente ter sido o único entre todos a não trair o movimento. Porém, ao longo do texto pode-se perceber um comportamento duvidoso e suspeito do real caráter do salvador do povo.

\footnotetext{
Mugo estava nervoso, deitado de costas olhando o teto. Mechas de fuligem pendiam do trançado de samambaia e capim, todas apontando para o seu coração. Uma gota d'água cristalina pendia delicadamente sobre ele. [...] Em desespero Mugo se concentrou pra se sacudir da situação de uma vez por todas e acordou. Agora jazia sob a coberta, ainda pertubado, temendo, como no sonho, que uma gota de água fria de repente penetrasse nos seus olhos (NGUGI, 2015, p. 17).
}

O personagem Kihika, o líder do partido, é um mártir que lutava contra a dominação dos brancos na aldeia Thabai, carregando consigo uma palavra de sabedoria que levasse o povo à melhor decisão. Para Oliveira (2018, p.208), o escritor Ngugi "elege heróis da sociedade e da história queniana que, por meio de seus exemplos e saberes, podem ter o mesmo efeito no mundo real". Com toda a perseguição que Kihika e seus homens faziam aos brancos, ao roubarem suas armas, matarem seus homens e soltarem os prisioneiros, Kihika passou a ser conhecido como "terror do homem branco. Diziam que ele podia mover montanhas e evocar o trovão do céu" (NGUGI, 2015, p.34).

Com a morte de Kihika, a população passa a ficar completamente vulnerável, tendo em vista que o representante do povo havia sido enforcado em uma árvore por colonizadores ingleses. Esta morte gerou uma incessante busca pelo traidor de Kihika, e entre os suspeitos estava Karanja, um jovem negro que resolveu se aliar aos brancos em troca de poder, embora o seu povo condenasse sua posição e o considerasse um traidor, por mudar de lado, ele "preferia aguentar a humilhação a perder o bom nome que conquistara entre os brancos" (NGUGI, 2015, p. 58).

A voz do líder, mesmo após seu assassinato, permanece viva dentro do desenrolar dos fatos no romance. Mesmo o corpo de Kihika ter sido deixado pendurado na árvore pelo colonizador para amedrontar a população do Quênia. O movimento "permaneceu vivo e cresceu, como se dizia, sobre as feridas dos que haviam sobrevivido a Kihika” (NGUGI, 2015, p.35). E aumenta a necessidade de encontrar homens que não recuassem da batalha que estava sendo travada com o homem 
branco pelo Quênia e que não se alie para o lado oposto, deixando de cumprir o juramento existente no movimento.

Mas o que é um juramento? Algumas pessoas precisam do juramento para ligá-las ao Movimento. Existem aqueles que não guardam o segredo a não ser obrigadas por um juramento. Eu conheço eles. Conheço os homens pelas suas caras. Aliás, quantos fizeram o juramento e agora estão lambendo os pés dos brancos? Não, você faz um juramento para confirmar uma opção já feita. A decisão de pôr ou não sua vida à disposição do povo mora no seu coração. O juramento é a água borrifada na cabeça durante o batismo (NGUGI, 2015, p. 239).

Com a ida de alguns homens suspeitos de participarem do movimento para campos de concentração, as mulheres passaram a assumir o papel de responsáveis pelo lar. E entre elas estava Mumbi, irmã de Kihika, tida como uma das mulheres mais belas entre as oito serranias. Ela era casada com Gikonyo, um carpinteiro que lutou junto ao movimento pela liberdade do Quênia. Mumbi assim como as outras mulheres tinham que trabalhar para trazer sustento ao lar, dentro de duas horas, tempo estabelecido pelos brancos para as mulheres irem atrás de comida.E pouco a pouco esse tempo foi sendo reduzido até que em determinado momento deixou de existir. Foi então que a população começou a passar fome, e as mulheres passaram a se subordinar a situações desesperadoras por comida.

Éramos prisioneiros na aldeia, e os soldados haviam construído todos os seus acampamentos em volta, para impedir qualquer fuga. Ficamos sem comida. O choro das crianças era terrível de ouvir. O novo chefe do distrito não ligava para o choro. Ele chegava a permitir que os soldados pegassem mulheres e as levassem para suas tendas. Meu Deus! Não sei como me livrei dessa vergonha. [...] Chegou o dia em que eu não aguentava mais. Devo dizer que a minha sogra e meus pais pareciam aguentar mais que eu. Quanto a mim, achava que não poderia viver mais um dia. [...] Quando entrei, senti vergonha, mesmo no meio da minha fome não pude contar a Wangari onde arranjara a comida. [...] Você sabe que naquela época as mulheres se ofereciam aos soldados por um pouco de comida, e eu não me sentia diferente (NGUGI, 2015, p. 181-184).

Embora muitos estivessem lutando contra os colonizadores, em busca da liberdade do Quênia, ainda existiam quenianos que se se aliavam com os brancos. O general R., um guerreiro que participou da guerra dos ingleses e mais tarde se aliou a Kihika para defender o Quênia, viveu situações de violência dentro do seu lar, e ao tentar defender a mãe de mais uma surra, acabou se decepcionando ao ver que a mãe preferia o marido que lhe espancava ao filho que lhe defendia. Ele então pode compreender só mais tarde, quando viu tantos quenianos capazes de defender orgulhosamente sua escravidão, foi que ele pôde compreender a reação da mãe.

O homem branco vivia na nossa terra. Comia do que cultivávamos e cozinhávamos. E até agora as migalhas da nossa mesa, ele as jogava 
para os seus cachorros. Foi então que fomos para a floresta. Quem não estivesse do nosso lado estava contra nós. Foi por isso que matamos nossos irmãos negros. Porque, por dentro, eles eram brancos. E, já sei que essa guerra ainda não terminou (NGUGI, 2015, p. 271).

No dia 12 de dezembro de 1963, o Quênia conquistou a liberdade. Isso fez com que a população vibrasse de alegria e saísse às ruas para cantar e celebrar. Foi então que a meia-noite muitas mulheres rodearam a cabana de Mugo, "elas cantaram para Kihika e Mugo, os dois heróis da libertação (homem branco. Diziam que ele podia mover montanhas e evocar o trovão do céu” (NGUGI, 2015, p. 252). Porém Mugo não saiu de dentro de sua cabana em nenhum momento, pois estava se sentindo angustiado com todos os acontecimentos. Embora a Uhuru tenha sido conquistada, ainda existiam muitas dúvidas em relação ao que viria no futuro, "o governo ficaria menos severo com aqueles que não podiam pagar impostos? Haveria mais empregos? Haveria mais terras? (homem branco. Diziam que ele podia mover montanhas e evocar o trovão do céu” (NGUGI, 2015, p. 265).

Ainda que a suspeita que o traidor que levou Kihika aos brancos tenha sido Karanja, o final do romance surpreende a toda a população de Thabai. Mugo foi escolhido para ser o orador na noite da Uhuru, porém ele se negou a discursar. O General R. decide então substitui-lo, e no meio de sua fala seria apontado o traidor de Kihika, para que toda a população soubesse quem era e para ser punido publicamente. Quando o General está pronto para apontar Karanja como culpado, Mugo sobe no palco e pede para falar, e então ele diz:

\footnotetext{
"Vocês queriam Judas?", começou ele. 'Vocês queriam o homem que levou Kihika a esta árvore aqui. Pois, este homem se encontra diante de vocês agora. Kihika veio me ver à noite. Ele depositou em minhas mãos, e eu a vendi ao homem branco. E isso tem destruído a minha vida todos esses anos'. Ele falou o tempo todo numa voz clara, dando um intervalo no final de cada frase. Ao chegar ao fim, no entanto, sua voz rachou e se reduziu a um sussurro. "Agora vocês sabem” (NGUGI, 2015, p. 273).
}

Com a descoberta tudo ficou mais claro, toda a valorização equivocada que a população fez de Mugo foi descartada ao ver que o herói, na verdade, era o traidor que levou Kihika à morte. E que diante de tudo isso deve-se priorizar a união do povo para que a retomada de uma nova nação, seja feita de uma maneira que ajude todos a superar as contradições que os africanos vivem após a colonização. E ajudar a curar marcas existentes da violência da colonização e descolonização.

\section{0 romance africano de Coetzee: as lições de Elizabeth Costello}

O sul-africano J. M. Coetzee, semelhante a outros escritores do continente africano, tratam em seus romances características importantes do seu país, em 
diálogo com à metrópole colonial, Coetzee inclusive já expôs temas polêmicos "escreveu inúmeros romances e livros sobre os efeitos perniciosos da censura e da opressão totalitária na África do Sul” (ROSENFIELD, 2013, p. 01).

Nesse contexto, em sua obra Elizabeth Costello (2004), o autor apresenta a biografia ficcional de Elizabeth Costello, uma escritora australiana com sessenta e seis anos, conhecida pela obra "A casa da rua Eccles", que a proporciona a realização de diversas palestras e viagens junto com seu filho John, que a ajuda em sua vida profissional "Elizabeth tem estado um pouco frágil: sem a ajuda do filho não teria podido enfrentar essa viagem desgastante através de metade do mundo" (COETZEE, 2004, p. 08).

Coetzee busca a aproximação entre leitor e narrador, por esse motivo, utiliza-se de artifícios estéticos, como a primeira pessoa do plural e a informalidade "mudemos de assunto" (COETZEE, 2004, p. 08). Trata-se de um romance com características muito singulares, no qual narrador, personagem e leitor se dialogam durante todo o enredo, as lições da personagem Elizabeth Costello são dadas através das palestras, não somente a seu privilegiado público do cruzeiro marítimo, mas aos leitores que a acompanham pelas páginas do livro.

Além de em alguns instantes a personagem expor opiniões semelhantes às do escritor, "as opiniões que ela expressa parecem refletir as de Coetzee ele mesmo, pelo menos na época em que o romance foi escrito, e acho que podemos seguramente concluir que ele a escolheu como sua porta-voz" (PHELPS, 2008, p. 02), o que ainda que de forma inconsciente aproxima mais esse diálogo leitor-autor.

Na constante busca literária de Coetzee de apresentar a importância da literatura africana e destacar seus pontos, em sua obra Elizabeth Costello (2004), o autor possui um capitulo intitulado "O romance na África”, que tem como cenário um cruzeiro, no qual a personagem principal é responsável para conduzir uma palestra. Durante o cruzeiro Elizabeth encontra um amigo o qual não o via há muitos anos, chamado Emmanuel Egudu, um escritor Nigeriano que vai palestrar sobre "O romance na África".

Coetzee possui aspectos literários interessantes em sua obra, ele transita entre a palestra de Egudu e os pensamentos de Elizabeth, inclusive em determinado instante indo contra Emmanuel, e explicando africanidade "Nós, africanos. Não é o nosso jeito. [...] Africanidade: uma identidade especial, um destino especial" (COETZEE, 2004, p. 48).

Em sua palestra sobre romance africano, Egudu diz que ele pode ser identificado como uma forma de crítica ao romance ocidental.

Os romances africanos é, portanto, eu afirmo, em seu próprio ser e antes da primeira palavra ser escrita, uma crítica ao romance ocidental, que avançou tanto no caminho da incorporeidade - como Henry James, como Marcel Proust - que o melhor jeito, na verdade o único jeito, de absorvê-lo é em silêncio é a solidão (COETEZEE, 2004, p. 52) 
Egudu explica e enfatiza em diversos momentos da palestra as dificuldades de se escrever no continente africano. "Na África, escrever, para não falar em escrever romance, é uma coisa recente” (COETZEE, 2004, p. 47). Esse trecho relata sobre a demora de ser ter romances escritos na África, pois apenas no século XX os africanos começaram a escrever obras, pois até então, os colonizadores escreviam.

As literaturas africanas se fortalecem enquanto fenômeno cultural em expansão mundial, gradualmente, a partir dos eventos de descolonização durante toda a metade do século XX. Por isso, só se pode pensar as composições narrativas africanas a partir da batalha ideológica pela tomada do poder simbólico para produzir discursos próprios, autônomos e culturalmente enriquecido por séculos de história (OLIVEIRA et al, 2019, p.4).

Conforme abordado pelo personagem de Coetzee, a escrita de romances por africanos é um fato muito recente, por isso, o destaque do palestrante ficcional ao paralelismo ao romance europeu. Trata-se de uma tentativa de desvinculação ou distanciamento dos modelos estéticos do romance ocidental, até pelo pouco tempo em que aos africanos lhe foram dadas as possibilidades de escrever sobre sua própria terra.

Em relação às dificuldades e limitações de se ter romances africanos, em seu discurso Egudu diz que "ler não é uma recreação tipicamente africana. Música, sim; dançar, sim; comer, sim; conversas, sim - muita conversa. Mas ler, não, principalmente não a leitura de grossos romances” (COETZEE, 2004, p. 47), conforme exposto pelo autor a literatura africana ainda não pode ser considerada uma marca cultural africana sui generis, outros aspectos culturais são associados ao continente. Uma perspectiva interessante abordada no romance durante a palestra de Egudu é a pobreza que o continente africano vive atualmente, que expõe tamanha desigualdade no mundo, conforme apresentado isso pode ser uma justificativa para a ausência de leitores na África, (COETZEE, 2004, p. 48) "no grande, beneficente sistema global em que vivemos hoje, coube à África ser a morada da pobreza. Africanos não tem dinheiro para luxos. Na África, um livro tem que oferecer algo em troca pelo dinheiro que se gastou nele".

Nesse ponto, questões pós-materialistas parecem estar distantes da população africana, chama-se a atenção às necessidades básicas do ser humano, para só assim podem pensar o papel que o romance africano desempenha na cultura do continente.

Nessa visão que os africanos não possuem acesso a suas próprias obras, após a palestra de Egudu, em um diálogo sobre essa questão com Elizabeth ela indaga "Os romances africanos podem escrever sobre a África, sobre experiências africanas, mas me parece que estão olhando por cima do ombro o tempo todo enquanto escreverem, para os estrangeiros que lerão seus livros" (COETZEE, 2004, p. 59). Ou seja, os romances africanos são escritos para estrangeiros, não para africanos, 
isso pode ser justificado pela colonização e eurocentrismo. A criação de uma identidade nacional se torna cada vez mais complexa de ser bem-sucedida, enquanto a nação não conhecer o que produz.

No diálogo que ocorre entre Elizabeth e Egudu, o autor resolve enfatizar e ressaltar novamente na fala da personagem a distância entre quem escreve e para quem é produzido o romance africano:

O romance inglês, diz "é escrito em primeiro lugar por ingleses para ingleses. É isso que faz dele o romance inglês. O romance russo é escrito por russos para russos. Mas o romance africano não é escrito por africanos para africanos (COETZEE, 2004, p. 59).

Com base em trechos do livro expostos, é notável a necessidade de John Maxwell Coetzee de falar sobre o continente africano, especificamente nessa obra ele se utiliza de métodos diretos, metaliterários, durante uma palestra na qual sua personagem principal está para expor sobre o romance africano, enfatizando, principalmente, as dificuldades da literatura de se aproximar dos africanos, Coetzee menciona os impactos causados pela colonização e pelo eurocentrismo, tudo isso num contexto onde se busca mostrar ao leitor a importância e necessidade da valorização dessa identidade africana.

\section{Considerações finais}

Em termos conclusivos, pode-se observar algumas características significativas neste conjunto de romances africanos, apresentados neste trabalho, com destaque às questões históricas que configuram o passado colonial das nações africanas, o seu próprio desdobramento através de processos políticos autoritários em alguns países e consequentemente, a questão racial materializada por experiências subjetivas e estruturais de discriminação e segregação. Em suma, é notável que em diversas obras, os aspectos temáticos, tais como a história dos países e as questões sociopolíticas, estão constantemente expostos e entrelaçados com enredos e tramas organizadas criativamente, assim como o constante encontro de culturas, decorrente do empreendimento colonial europeu na África. Dessa maneira, autores como Nadine Gordimer, Pepetela, Ngugi Wa Thiong’o e Coetzee são necessários para a história cultural da África, na medida em que possam dar voz a outros discursos não-eurocêntricos e que tomem a diversidade africana como material poético de escrita ficcional naturalmente solidária e dialógica.

Retratar nas obras literárias esse novo cenário pós-colonial incentiva a desconstrução dos estereótipos construídos ao longo de décadas e desmancha a visão eurocêntrica de subjugamento e inferioridade africana. Portanto, o potencial para a subversão da língua, gêneros, temas e valores ainda não se realiza, plenamente, 
nesses textos pós-coloniais, que são produzidos num contexto marcado por discursos e condições materiais restritivas para a produção da literatura, mas que se fortalece enormemente ao longo das décadas recentes. Faz-se necessária a escrita e a leitura desses romances, a fim de contribuir na reconstrução de identidades africanas, a partir da utilização de um gênero de origem ocidental, mas que permite o registro de vivências e subjetividades plurais de diferentes povos do continente. Além disso, as marcas locais da história, da política e da cultura do continente podem representar procedimentos de inovação e atualização do próprio gênero literário. Desse modo, a literatura africana é para todos, africanos, europeus, americanos e asiáticos, e com base nela se pode ter uma valorização e reconhecimento de sociedades milenares.

\title{
HISTORY, POLITICS AND SOCIETY: A THEMATIC ANALYSIS OF POST-COLONIAL AFRICAN LITERATURES
}

\begin{abstract}
This article analyzes a set of works representative of post-colonial African literature, based on thematic clippings that move between the history and politics of African societies. The work presents a series of critical readings on the works No time like the present (2014) by Nadine Gordimer, A Grain of Wheat (2015) by Ngugi Wa Thiong'o, The Plateau and the Steppe (2009) by Pepetela and Elizabeth Costello (2004) by J. M. Coetzee, in order to point out the great themes of these literatures, with emphasis on the colonial issue and its unfolding in the present, the political history of African nations and racial discrimination, as fundamental elements to understand the African literary universe.
\end{abstract}

Keywords: African Literature. Novel. Theory. Post-Colonialism

\section{Referências:}

AUGEL, Moema P. O desafio do escombro: nação, identidades e pós-colonialismo na literatura da Guiné-Bissau. Rio de Janeiro: Garamond, 2007.

BOEHMER, E. Colonial and postcolonial literature: migrant metaphors.

2. ed. Oxford: Oxford University, 2005.

BONNICI, Thomas. Introduction to the study of post-colonial literatures.

Mimesis, Bauru, v. 19, n. 1, p. 07-23, 1998.

CARBONIERI, Divanize. FREITAS, João F. SILVA, Sheila D.

Rumos do romance africano de língua inglesa na contemporaneidade.

Revista Investigações. v. 26 n.1, 2013.

COETZEE, John Maxwell. Elizabeth Costello. São Paulo:

Companhia de letras, 2004. 
GORDIMER, Nadine. O melhor tempo é o presente. São Paulo: Companhia das Letras, 2014.

HALL, Stuart. A identidade cultural na pós-modernidade. Rio de Janeiro: DP\&A, 2004.

JULIEN, Eileen. African Literature in Comparative Perspective. Comparative and general literature. v.43, p. 15-24, 1995.

KANTER, Marcelo de Mello. A política externa e integração da África Oriental: um estudo sobre Uganda, Tanzânia e Quênia. Dissertação (Mestrado) Universidade Federal do Rio Grande do Sul, Faculdade de Ciências Econômicas, Porto Alegre, 2015.

MATA, Inocência. Literaturas em português: encruzilhadas atlânticas. Revista Via Atlântica, nº25, 59-82, São Paulo, jul.,2014.

MENEZES, Maria Paula. Os sentidos da descolonização: uma análise a partir de Moçambique. Catalão, v. 16, n. 1, p. 26-44, 2016.

NKOSI, L. Tasks and Mask: Themes and Styles of African Literature. Oxford: Longman, 1981.

OJAIDE, Tanure. Modern African Literature and Cultural Identity. African Studies Review, v. 35, Number 3, December, 1992 pp. 43-57.

OLIVEIRA, Adilson V. Literatura e política: as contradições do socialismo em “O planalto e a estepe”. Revista Ecos vol. 16, Ano XI; nº 01, 2014.

OLIVEIRA, Adilson V.; PIOVEZAN, Vitória; ALMEIDA, Thaís F.; BERSANI, Ana Cássia; PINHEIRO, Karen. Literaturas africanas: a história na composição narrativa. Revistas África[s] v. 5, n. 9, 2019, p.134-153

OLIVEIRA, Bruno R. Ngugi Wa Thiong'o: o percurso de um intelectual africano e a história do Quênia (1964-1985). MÉTIS: história \& cultura. p. 205-228, jan./jun. 2018.

PAWLICKI, Marek. Perspectives on Past and Present Realities: Nadine Gordimer's Voice on Social and Political Problems in South Africa. Kultura i Polityka, n. 15, p. 173-186, 2013.

PEPETELA. O planalto e a estepe. $1^{\text {a }}$ ed. São Paulo: Leya, 2009.

PHELPS, Norm. Rhyme, Reason, and Animal Rights: Elizabeth Costello's Regressive View of Animal Consciousness and its Implications for Animal Liberation. Journal for Critical Animal Studies, V. 6, n. 1, 2008.

RIESZ, J. De la littérature coloniale à la littérature africaine: pretextes, contextes, intertextes. Paris: Karthala, 2007.

ROSENFIELD, Kathrin. Coetzee e a censura: o ético na perspectiva do escritor. Revista Intuitio. Porto Alegre, v. 7, p. 05-16, 2014. 
SALGADO, T.; SEPÚLVEDA, M. do C. África e Brasil: letras e laços. Rio de Janeiro: Atlântica, 2000.

SOYINKA, Wole. Indanre and other poems. London: Eyre Methuen, 1967.

SPIVAK, Gayatri. Quem reivindica a alteridade. In: HOLANDA, Heloisa.B. de (Org.). Tendências e impasses: o feminismo como crítica da cultura.

Rio de Janeiro: Rocco, 1994. p. 53-75.

THIONG’O, Ngugi wa. Um grão de trigo. Rio de Janeiro: Objetiva, 2015.

Recebido em 12 de março de 2021

Aprovado em 22 de maio de 2021 